\title{
Cost to the cavity-nest ant Temnothorax crassispinus (Hymenoptera: Formicidae) of overwintering aboveground
}

\author{
SŁAWOMIR MITRUS \\ Department of Biosystematics, Laboratory of Evolution and Animal Ecology, Opole University, Oleska 22, 45-052 Opole, Poland; \\ e-mail: smitrus@uni.opole.pl
}

Key words. Formicidae, Temnothorax crassispinus, percentage survival, overwintering

\begin{abstract}
Most species of ants inhabiting the temperate zone overwinter underground, whereas those of the genus Temnothorax remain in nests aboveground. I studied the cost of aboveground overwintering. Workers of Temnothorax crassispinus survived in higher numbers (median $=88 \%$ ) in artificial nests experimentally buried at a depth of $5 \mathrm{~cm}$ than those in nests on the surface $(48 \%)$ of the soil. The results support the hypothesis that overwintering aboveground could be a consequence of a limited supply of nests and/or the advantage of being able to respond quickly to warm temperatures in spring.
\end{abstract}

\section{INTRODUCTION}

Overwintering insects in temperate zones can experience extreme physical conditions. Thus, many species possess physiological adaptations that improve their chances of surviving cold winter weather (such as high concentrations of cryoprotectants) (Leather et al., 1995; Bale et al., 2010). In addition, selection of the overwintering site is also of great importance in determining survival (Leather et al., 1995; Heinze et al., 1996). Ants are typically highly abundant in almost all terrestrial ecosystems (Wilson \& Hölldobler, 2005). Probably most species of ants inhabiting the temperate zone overwinter underground, but cavity-nesting ants of the genus Temnothorax remain aboveground throughout the winter (Herbers, 1989), during which time they could be exposed to extremely cold conditions. Such exposure should lower their survival, so overwintering aboveground (compared to overwintering in the soil) should provide benefits that outweigh the mortality costs associated with such behaviour.

Ants of the genus Temnothorax belong to the myrmicine tribe Formicoxenini and are among the most widely distributed and most common ants in Central Europe. Colonies of this species are very small, ranging from a few dozen to hundreds of workers and they nest in cavities in wood, hollow acorns, hazelnuts, pieces of bark, or rotting branches on the ground, but also under moss, stones and in litter (Czechowski et al., 2002; Seifert, 2007). The colonies are usually monogynous (i.e., have one queen) (Heinze \& Buschinger, 1988; Seifert, 2007), although separate colonies may integrate before winter (Seifert, 2007). The life history aspect that may account for the puzzling overwintering behaviour of Temnothorax ants could be strong competition for nest sites (Herbers, 1989; Herbers \& Banschbach, 1995; Foitzik \& Heinze, 1998; DeHeer \& Herbers, 2004). It is possible they overwinter on the surface because it is advantageous to occupy and remain in good nest sites because they are in limited supply (Herbers, 1989; Herbers \& Johnson, 2007). I hypothesize that the ants stay aboveground rather than move underground during the winter, because the costs of exposure to cold temperatures are lower than the benefits of being in a good nest site the following spring. However, the real costs of aboveground overwintering are not known. In this paper I present results of a field experiment on the winter mortality of cavity-nesting ants that overwinter aboveground compared to those that overwinter in the soil.

\section{MATERIAL AND METHODS}

The experiment was conducted on the wood-dwelling ant Temnothorax crassispisus in a beech-pine forest close to Opole $\left(50^{\circ} 37^{\prime} \mathrm{N}, 18^{\circ} 07^{\prime} \mathrm{E}\right)$. This species is widely distributed throughout Poland (Czechowski et al., 2002). In the experimental area the density of colonies of $T$. crassispinus is high, however precise data is not available (in a similar area about $2 \mathrm{~km}$ northeast of the experimental area there were an average of 2.5 ant nest sites per $\mathrm{m}^{2}$ in June 2010 and $1.6 \mathrm{nest} / \mathrm{m}^{2}$ in August 2010; Białas et al., 2011).

Fifty one ant colonies were collected in the experimental area on 14-21 October 2011, and transported to laboratory. They included 45 colonies in twigs and 6 in acorns. In addition, two small twigs with lone queens and one with only two workers were found. In the laboratory the nests were carefully opened, the ants captured with an aspirator and counted. Of the 51 colonies, 17 were queen less and 40 had queens ( 34 one queen, 3 three queens and three colonies had 2, 4 and 5 queens, respectively). The queen less colonies contained a smaller number of workers than those with queens (queen less: median number of workers 24.0, range 5-180; colonies with queens: median 153.5, range 5-366; Mann-Whitney $U$ test: $U=121.0, P<0.001$ ). There were no differences in the number of workers in colonies with one and with several queens (t-test: $t=0.023, P=0.98$, df $=38$ ).

The colonies were standardized because the number of workers in the colonies was very variable. From each original colony, one or two experimental (sub)colonies were created, each of which included 75 randomly chosen workers and, if present, one queen. In all cases, this procedure resulted in subsets of large colonies, not a mixture of ants from several colonies. The experimental colonies were placed in square plastic Petri dishes $(10.2 \mathrm{~cm} \times 10.2 \mathrm{~cm} \times 1.9 \mathrm{~cm})$ with a thin plaster base. The plaster was watered regularly. Each Petri dish contained a single artificial nest consisting of a piece of birch wood $(1.4 \mathrm{~cm}$ $\times 1.4 \mathrm{~cm}$ and $7 \mathrm{~cm}$ long) with a longitudinal cavity $4 \mathrm{~mm}$ in diameter. One end of the cavity was blocked with a piece of pine wood and the other partially closed with a splinter of wood; thus the final volume the chamber was about $750 \mathrm{~mm}^{3}$. A 
marker consisting of a $1.5 \mathrm{~cm}$ piece of plastic tape embossed with a unique number was glued to each nest. Ants were fed twice a week with honey and dead fruit flies, Drosophila hydei. Dead workers were counted and removed. The Petri dishes were kept in a thermostatic cabinet maintained at a temperature of $5^{\circ} \mathrm{C}$ during the $12 \mathrm{~h}$ of dark period ("night") and $10^{\circ} \mathrm{C}$ during the $12 \mathrm{~h}$ of light period ("day") until 18th November.

Several colonies did not accept the artificial nests. Thus, eventually, I used 36 colonies (18 with a queen and 18 without a queen) each containing 66-75 workers (median 73 , quartiles: 71.5-74) in the experiment. From 18 November onwards the temperature in the thermostatic cabinet was gradually reduced to $3^{\circ} \mathrm{C}$. On 22 November the entrances to the artificial nests were closed with a metal netting to prevent the ants from escaping.

From 4 November 2011, the temperature on the ground and in the soil at a depth of about $5 \mathrm{~cm}$ in the research area was monitored at two-hour intervals using a datalogger AZ 88128. On 24 November 2011, after the first frost, but prior to the first severe frost (on 11 November and 20 December, respectively), artificial nests containing the colonies were placed into a field enclosure in an area of about $1 \mathrm{~m} \times 3 \mathrm{~m} ; 18$ nests $(9$ with queens and 9 without queens) were placed on the ground and the other 18 (9 with and 9 without queens) carefully buried in the soil at a depth of about $5 \mathrm{~cm}$. The 36 experimental colonies came from 28 nests collected in the field, for each of the eight nests that gave rise to two experimental colonies one was randomly chosen as the experimental colony to be placed on the ground and the other buried in the soil. Each the artificial nests was tied by a nylon thread to small wooden peg stuck in the ground.

During the experiment the average aboveground temperature in the study area was $+0.08^{\circ} \mathrm{C}$ (median $=+0.70^{\circ} \mathrm{C}$, range -13.7 $\pm 9.9^{\circ} \mathrm{C}, 25-75 \%$ quantiles $\left.-1.4 \pm 3.1^{\circ} \mathrm{C}\right)$ and that at $5 \mathrm{~cm}$ below the surface of the ground $+1.66^{\circ} \mathrm{C}$ (median $=+2.30^{\circ} \mathrm{C}$, range $-6.6 \pm 7.4^{\circ} \mathrm{C}, 25-75 \%$ quantiles $\left.-0.5 \pm 4.3^{\circ} \mathrm{C}\right)$. Winter temperatures were typical for this part of Poland but there was a shorter than normal period of snow cover; the first snow fell on 21 December 2011 and most days were without snow cover (cf. Lorenc, 2005; Kożuchowski, 2011).

The following spring, on 6 March 2012, all the artificial nests were collected and kept under a daily cycle of $14 \mathrm{~h}$ of dark ("night") at a temperature of $7^{\circ} \mathrm{C}$ and $10 \mathrm{~h}$ of light ("day") at $14^{\circ} \mathrm{C}$ for two days. Then the nests were carefully opened and live ants were counted.

Statistical analyses were carried out using the software package Statistica, ver. 10. (StatSoft Inc., 2011).

\section{RESULTS}

The percentages of the worker ants that survived in individual nests during winter varied from 0 to $100 \%$. In two nests (one with and the other without a queen and both situated aboveground) all the ants died during winter. There were no significant differences in queen survival, although it appeared to be lower in the aboveground nests ( 5 of 9 queens) than in nests at a depth of $5 \mathrm{~cm}$ ( 7 of 9 queens; Fisher exact test, $P=0.31$ ). Workers at depths of $5 \mathrm{~cm}$ survived in higher numbers (median $=87.9 \%)$ than aboveground (48.4\%) (Mann-Whitney U test: $U$ $=38.0, P<0.0001 ;$ Fig. 1$)$. There were no difference in the percentages of workers that survived in colonies with and without queens in nests situated aboveground and at a depth of $5 \mathrm{~cm}$, respectively (Mann-Whitney U tests; aboveground: $U=31.5, P$ $=0.45$, and below ground: $U=27.0, P=0.25$ ).

\section{DISCUSSION}

Ants of most species overwinter underground, however ants of the genus Temnothorax are known to spend winter in nests

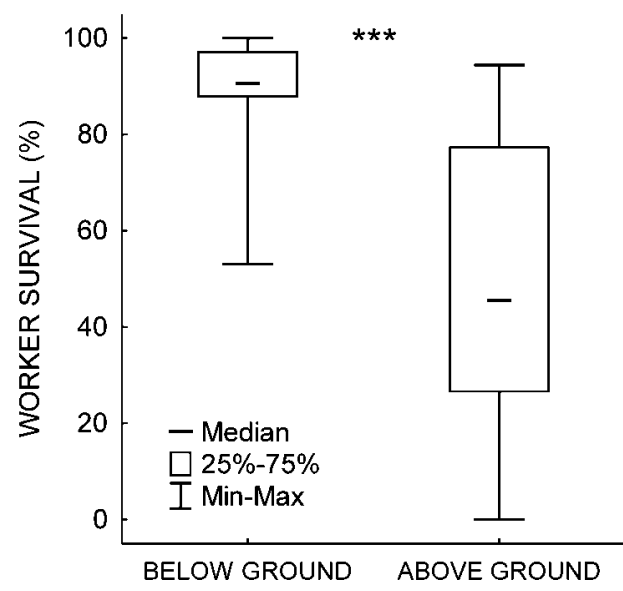

Fig. 1. Percentage survival of workers of the ant Temnothorax crassispinus that overwintered in artificial nests situated $5 \mathrm{~cm}$ below the surface (left) and on the surface (right). Symbols: *** $-P<0.0001$ (Mann-Whitney U test of differences in medians).

situated on the ground (Herbers, 1989) and thus face possible exposure to severe frosts as well to high temperatures. For example, the overwintering survival and body fat resources of the forest-dwelling wood ant Formica aquilonia are lower when the temperature during winter is higher (Sorvari et al., 2011). Overwintering above ground could be because of limited numbers of suitable nesting sites, but its real costs have not previously been studied. This study has shown that in artificial nests below ground the percentage survival of Temnothorax crassispinus workers overwinter is higher than in nests situated aboveground. This indicates that the position of the nest sites occupied during winter could be important in determining the future survival of a colony.

Survival during winter is crucial for animals living in the temperature zone. Many species survive in places that protect them against extreme temperatures (e.g. under the soil surface) or have special adaptations that enable them to survive very low temperatures (Heinze, 1993; Leather et al., 1995). It is unknown whether the ant $T$. crassipinus has any physiological adaptations that enable it to withstand low temperatures. Although they could have such adaptations, this study shows that overwintering aboveground is costly and thus it is likely they overwinter in nests on the surface because there is strong competition for good nest sites. The great variation in the percentage of worker surviving overwinter in different nests $(0-100 \%)$ is in accordance with that previously reported (e.g. Herbers, 1986; Herbers \& Johnson, 2007). During the experiments the ants remained in the nests, but in the wild up to one third of the colonies of the ant $T$. curvispinosus relocate during the cold months (Herbers \& Johnson, 2007). The lack of opportunities for moving in this study could have affected the percentage survival, as could the lack of snow cover, as the temperature of soil covered with snow is considerably higher than that not covered with snow (Leather et al., 1995; Bale et al., 2010).

Most species of ants living in areas subject to very cold winters overwinter underground (cf. Bale et al., 2010; Berman et al., 2010). For example, most species of ants in the Upper Kolyma area (average January temperature: about $-35^{\circ} \mathrm{C}$ ) overwinter deep beneath the surface, but the ant Leptothorax acervorum, which belongs to the same tribe as Temnothorax, spends winter at a depth of only 5-7 cm (Berman et al., 2010). Berman et al. (2010) suggest that by overwintering close to surface enables this ant to become active earlier in spring than other species of ants. Thus, by overwintering in aboveground nests 
ants of the genus Temnothorax are better able not only to occupy the best nest sites but also start foraging earlier the following spring and relocate their nest site during winter.

ACKNOWLEDGEMENTS. I would like to thank K. Błachut for her help in the laboratory. The work was supported financially by grant number $3 / \mathrm{KBi} / 11-\mathrm{S}$ from Opole University. Research in the experimental area was made possible with the kind permission of the Forest District Office in Opole. Three anonymous reviewers provided valuable comments on previous drafts of the manuscript. I also thank R. Tertil and I. Harman, both of Letterman, Translators \& Interpreters, who provided linguistic corrections.

\section{REFERENCES}

BALE J.S. \& HaYward S.A.L. 2010: Insect overwintering in a changing climate. - J. Exp. Biol. 213: 980-994.

Berman D.I., Alfimov A.V., Zhigulskaya Z.A. \& Leirikh A.N. 2010: Overwintering and Cold-Hardiness of Ants in the Northeast of Asia. Pensoft, Sofia, Moscow, 294 pp.

Bialas B., Granieczny P., Pędzisz A. \& Mitrus S. 2011: Colony size, density and type of nesting sites of the ant Temnothorax crassispinus (Hymenoptera: Formicidae). - Opole Sci. Soc. Nat. J. 44: 185-191.

Czechowski W., Radchenko A. \& Czechowska W. 2002: The Ants (Hymenoptera, Formicidae) of Poland. Museum and Institute of Zoology PAS, Warszawa, $200 \mathrm{pp}$.

DeHeer C.J. \& Herbers J.M. 2004: Population genetics of the socially polymorphic ant Formica podzolica. - Insectes Soc. 51: 309-316.

FoITZIK S. \& HeInZe J. 1998: Nest site limitation and colony takeover in the ant Leptothorax nylanderi. - Behav. Ecol. 9: 367-375.

HeInze J. 1993: Life histories of subarctic ants. - Arctic 46 : 354-358.
Heinze J. \& Buschinger A. 1988: Polygyny and functional monogyny in Leptothorax ants (Hymenoptera: Formicidae). - Psyche 95: 309-325.

Heinze J., Stah M. \& HöLldobler B. 1996: Ecophysiology of hibernation in boreal Leptothorax ants (Hymenoptera: Formicidae). - Ecoscience 3: 429-435.

Herbers J.M. 1986: Effects of ecological parameters on queen number in Leptothorax longispinosus (Hmenoptera: Formcidae). - J. Kansas Entomol. Soc. 59: 675-686.

HeRBERS J.M. 1989: Community structure in north temperate ants: temporal and spatial variation. - Oecologia 81: 201-211.

Herbers J.M. \& Banschbach V.S. 1995: Size-dependent nest site choice by cavity-dwelling ants. — Psyche 102: 13-17.

Herbers M.J. \& Johnson A.C. 2007: Social structure and winter survival in acorn ants. - Oikos 116: 829-835.

Kożuchowski K. 2011: Klimat Polski. Nowe Spojrzenie. [Climate of Poland. A New Look.] Wydawnictwo Naukowe PWN, Warszawa, 293 pp.

Leather S.R., Walters K.F.A. \& Bale J.S. 1995: The Ecology of Insect Overwintering. Cambridge University Press, Cambridge, $255 \mathrm{pp}$.

Lorenc H. (ed.) 2005: Atlas Klimatu Polski. [Climate Atlas of Poland.] Instytut Meteorologii i Gospodarki Wodnej, Warszawa, $116 \mathrm{pp}$.

SeIfert B. 2007: Die Ameisen Mittel- und Nordeuropas. Lutra, Görlitz, 368 pp.

Sorvari J., HaAtanen M.K. \& Vesterlund S.R. 2011: Combined effects of overwintering temperature and habitat degradation on the survival of boreal wood ant. - J. Insect Conserv. 15: 727-731.

StatSoft Inc. 2011: STATISTICA (Data Analysis Software System), Version 10. www.statsoft.com.

WiLSON E.O. \& Hölldobler B. 2005: The rise of the ants: A phylogenetic and ecological explanation. - Proc. Natl. Acad. Sci. USA 102: 7411-7414.

Received April 24, 2012; revised and accepted August 14, 2012 